\title{
Effect of Magnesium and Aluminum Oxides on Fluidity of Final Blast Furnace Slag and Its Application
}

\author{
Jia-Shyan Shiau*, Shih-Hsien Liu and Chung-Ken Ho \\ Department of Iron and Steel Research and Development, China Steel Corporation, Kaohsiung, 81233 Taiwan, R. O. China
}

Generally, decreasing slag volume of blast furnace operation can lead to the lower fuel ratio and higher productivity. For high sinter ratio operation, one of effective ways to obtain a lower slag volume is to reduce the gangue content of sinter. Basically, lowering the amount of serpentine in the sinter mix is a feasible way to produce suitable sinter with the lower gangue content. However, this method may result in lower magnesium oxide content in the final slag that may affect its fluidity. Hence, the objective of this study was to understand the effect of MgO and $\mathrm{Al}_{2} \mathrm{O}_{3}$ on the fluidity of final slag. The liquidus temperature and viscosity of semi-synthetic slag were measured using optical softening temperature device and viscometer, respectively, and the data were treated to develop the multiple-regression formula of $\mathrm{SiO}_{2}-\mathrm{Al}_{2} \mathrm{O}_{3}-\mathrm{CaO}_{-}$ $\mathrm{MgO}-\mathrm{TiO}_{2}$ semi-synthetic slag for liquidus temperature, viscosity equations and iso-fluidity diagrams.

The experimental results indicated that the lower liquidus temperature and the better viscosity stability lay in the area of $\mathrm{MgO}=5.4 \%$, $\mathrm{Al}_{2} \mathrm{O}_{3}=10-15 \%, \mathrm{TiO}_{2}=0.5 \%$ and $\mathrm{C} / \mathrm{S}=1.2$ for the range of composition studied. Several observations in the iso-fluidity diagrams of blast furnace final slag have shown that liquidus temperature decreased with decreasing $\mathrm{MgO}$ content and the viscosity of slag could be regarded as being independent of $\mathrm{MgO}$ content in the range of $\mathrm{MgO}=5-9 \%, \mathrm{Al}_{2} \mathrm{O}_{3}=15 \%, \mathrm{C} / \mathrm{S}=1.0-1.2$. And, slag fluidity became worse with increasing $\mathrm{Al}_{2} \mathrm{O}_{3}$ content under the conditions of $\mathrm{MgO}=5.4 \%, \mathrm{C} / \mathrm{S}=1.2$. This study suggested the $\mathrm{MgO}$ contents could be lowered from current 6.5 to $5.4 \%$ in the conditions of $\mathrm{Al}_{2} \mathrm{O}_{3}=15 \%, \mathrm{C} / \mathrm{S}=1.2$ under the stable blast furnace operation with high thermal level. Furthermore, this recipe of lower $\mathrm{MgO}$ content $(5.4 \%)$ had been implemented in CSC's BF operation to reduce the slag volume, and the formula of fluidity developed in this study had been installed in the process computer of all CSC's BFs to present slag fluidity in real time. [doi:10.2320/matertrans.M2012170]

(Received May 7, 2012; Accepted May 28, 2012; Published July 11, 2012)

Keywords: blast furnace $(B F)$ slag fluidity, liquidus temperature, viscosity, magnesium oxide, aluminum oxide

\section{Introduction}

The blast furnace final slag is made from the meltdown liquid of sinter, lump ore, coke and flux at high temperature, and can be approximately considered as a mixture of the five oxides, $\mathrm{SiO}_{2}, \mathrm{Al}_{2} \mathrm{O}_{3}, \mathrm{CaO}, \mathrm{MgO}$ and $\mathrm{TiO}_{2}$. There are four kinds of slags with distinct compositions produced at different regions inside the blast furnace via a series of reducion reactions. That is, primary slag, bosh slag, tuyere slag and final slag are respectively generated in the cohesive zone, dripping zone, raceway and hearth. As well known, good tapping is primarily based on the fluidity of the final slag (low liquidus temperature and low viscosity).

Generally, the major operating region of blast furnace slag for good fluidity in the quinary system $\left(\mathrm{SiO}_{2}-\mathrm{Al}_{2} \mathrm{O}_{3}-\right.$ $\mathrm{CaO}-\mathrm{MgO}-\mathrm{TiO}_{2}$ ) liquidus diagram is the melilites phase (solid solutions of akermanite, $\mathrm{Ca}_{2} \mathrm{MgSi}_{2} \mathrm{O}_{7}$, and gehlenite, $\mathrm{Ca}_{2} \mathrm{Al}_{2} \mathrm{SiO}_{7}$ ). And, decreasing the slag volume of the blast furnace operation can obtain the lower fuel ratio and higher productivity. For the high sinter ratio operation, one effective way to reach the lower slag volume is to reduce the gangue content of sinter. Basically, lowering the amount of serpentine in the raw mix is a feasible way to produce the qualified sinter with lower gangue. However, this method may result in the lower content of $\mathrm{MgO}$ and the higher content of $\mathrm{Al}_{2} \mathrm{O}_{3}$ in the final slag. The average data of China Steel Corporation (CSC) BF final slag in 2007 are summarized in Table 1. It can be seen that this $\mathrm{MgO}$ content ranged from 6.4 to $6.7 \%$, the $\mathrm{Al}_{2} \mathrm{O}_{3}$ and $\mathrm{TiO}_{2}$ content was around 15 and $0.55 \%, \mathrm{C} / \mathrm{S}$ was controlled within 1.18 to 1.20 , and the hot metal temperature (HMT) was around $1500^{\circ} \mathrm{C}^{1)}$

*Corresponding author, E-mail: jiashyanshiau@gmail.com
Table 1 Average data of $\mathrm{MgO}, \mathrm{Al}_{2} \mathrm{O}_{3}, \mathrm{TiO}_{2}, \mathrm{C} / \mathrm{S}$ and HMT for CSC's BF final slag in 2007.

\begin{tabular}{ccccc}
\hline Items & $1 \mathrm{BF}$ & $2 \mathrm{BF}$ & $3 \mathrm{BF}$ & $4 \mathrm{BF}$ \\
\hline $\mathrm{MgO}(\%)$ & 6.7 & 6.5 & 6.4 & 6.5 \\
$\mathrm{Al}_{2} \mathrm{O}_{3}(\%)$ & 14.8 & 15.2 & 15.0 & 15.2 \\
$\mathrm{TiO}_{2}(\%)$ & 0.50 & 0.50 & 0.67 & 0.57 \\
$\mathrm{C} / \mathrm{S}(-)$ & 1.18 & 1.19 & 1.20 & 1.20 \\
$\mathrm{HMT}, T /{ }^{\circ} \mathrm{C}$ & 1504 & 1504 & 1497 & 1495 \\
\hline
\end{tabular}

Therefore, the objective of this study was to evaluate the effect of $\mathrm{MgO}$ on the fluidity of the blast furnace final slag and find the appropriate $\mathrm{MgO}$ level for better $\mathrm{BF}$ performance. A final slag fluidity database will be built for reference on burden preparation of blast furnace by using the experimental results and calculated iso-fluidity diagrams.

\section{Experimental Method}

\subsection{Experimental apparatus}

The measurements of the liquidus temperature and viscosity of semi-synthetic slag were made by using an optical softening temperature device and a viscometer, respectively.

\subsubsection{Optical softening temperature device}

The experimental set-up was used for measuring the softening temperature of the slag by observing the deformation of the sample. Its schematic diagram is shown in Fig. 1. A horizontal tube furnace that can be heated up to a maximum temperature of $1700^{\circ} \mathrm{C}$ was used. Each end of the reaction tube was properly sealed by water-cooling metal 


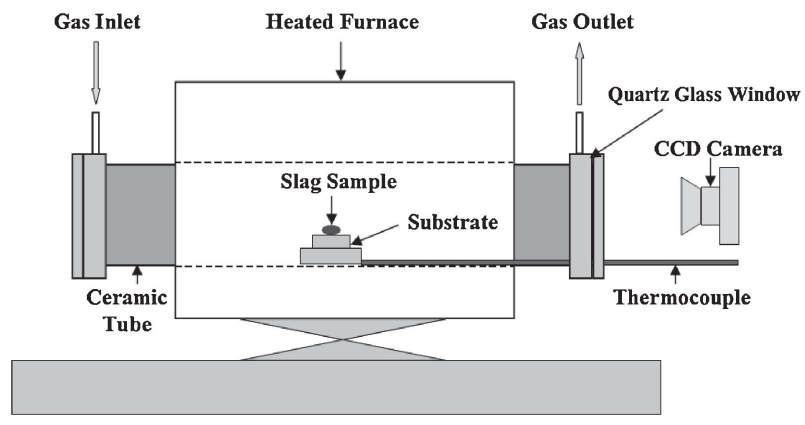

Fig. 1 The schematic diagram of experimental apparatus for the measurement of the softening temperature.

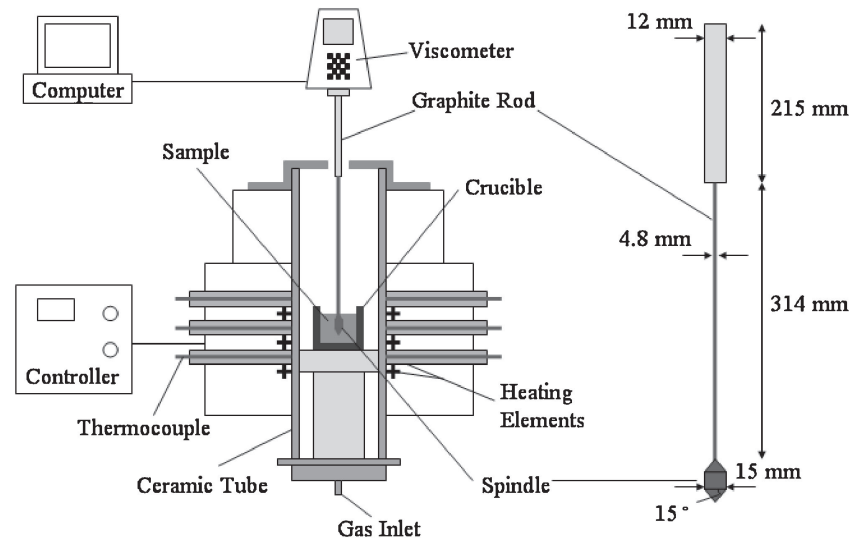

Fig. 2 The schematic diagram of experimental apparatus for the viscosity measurement.

caps to prevent air entering into the system, and closed by a quartz window allowing the CCD camera to follow the experiments visually. A thermocouple was inserted into the furnace through the quartz window, and the reaction tube was purged with Ar gas throughout the duration of experiment. In this experiment, approximately $0.07 \mathrm{~g}$ of cylindrical slag sample (outside diameter: $3 \mathrm{~mm}$, height: $3 \mathrm{~mm}$ ) was placed on the $\mathrm{MgO}$ substrate kept in the ceramic reaction tube.

\subsubsection{Viscometer}

A rotating cylindrical method was adopted to measure the viscosity of the molten slag. The apparatus is schematically shown in Fig. 2. A viscometer is connected to a graphite spindle through a graphite rod. The spindle consists of a bob and a shaft, of which the dimensions are also shown Fig. 2. The graphite crucible has a $50 \mathrm{~mm}$ internal diameter, $140 \mathrm{~mm}$ height, and $10 \mathrm{~mm}$ thickness of wall and base. The graphite crucible containing the slag sample (about $120 \mathrm{~g}$ of mixed powder) was placed in a given position of the heated furnace where the temperature distribution was uniform. The slag samples were kept molten for more than $2 \mathrm{~h}$, and the rotating spindle was then completely immersed into the molten samples. The holding time for reaching equilibrium state was more than $20 \mathrm{~min}$ at each experimental temperature. A metal flange was used to fill the gap between the ceramic reaction tube and the viscometer, and Ar gas was introduced into the reaction chamber at $0.4 \mathrm{~L} / \mathrm{min}$. The viscometer was calibrated by using Brookfield standard solutions with 0.5-49 poise $(1$ poise $=0.1 \mathrm{~Pa} \cdot \mathrm{s})$ at room temperature.

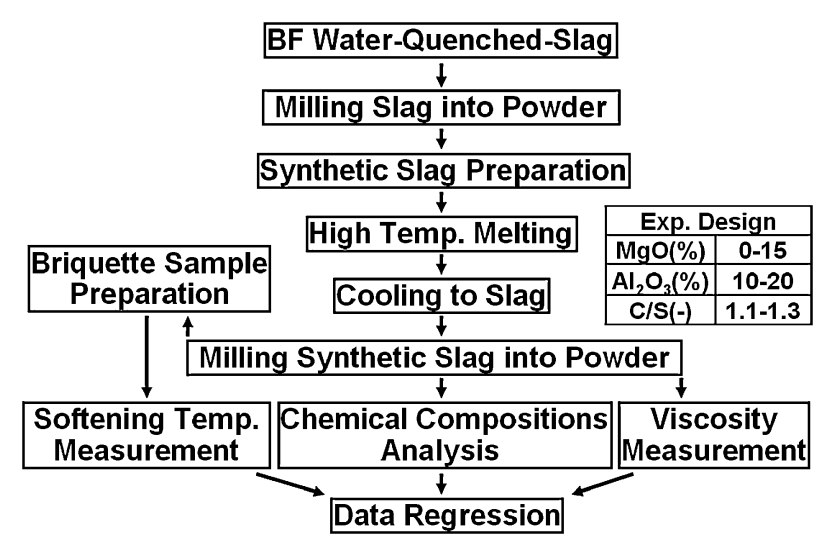

Fig. 3 The experimental approach for fluidity measurement in this study.

\subsection{Experimental procedure}

The experimental approach with above apparatus for the fluidity measurement in this study is given in Fig. 3. At the beginning, the semi-synthetic slag samples were the waterquenched slag obtained from the blast furnace, and prepared with different $\mathrm{MgO}$ contents and $\mathrm{C} / \mathrm{S}$ by adding pure oxide powers (reagent grade). In order to prepare a uniform slag, 110-120 g of mixed $\mathrm{SiO}_{2}-\mathrm{CaO}-\mathrm{Al}_{2} \mathrm{O}_{3}-\mathrm{MgO}-\mathrm{TiO}_{2}$ slag was pre-melted in a graphite crucible under the atmosphere of $\mathrm{Ar}$ gas $(0.4 \mathrm{~L} / \mathrm{min})$ at $1500^{\circ} \mathrm{C}$. Afterward, the melt was cooled to form solid (slag), and the solid milled into fine powder. Subsequently, three kinds of measurements on the slag samples were conducted at the same time: (1) preparation of briquette samples, followed by heating the samples to measure the slag softening temperatures by observing their deformation as shown in Fig. 4; (2) analysis of the slag chemical compositions; (3) measuring the slag viscosity by using a viscometer at high temperature. Finally, the measured data for liquidus temperature and viscosity was processed by the multiple regression method to get mathematic equations, and the iso-fluidity diagrams could be developed by combining the equation: $\mathrm{SiO}_{2}+\mathrm{CaO}+\mathrm{Al}_{2} \mathrm{O}_{3}+\mathrm{MgO}+$ $\mathrm{TiO}_{2}=100 \%$.

The original form of a briquette sample is shown in Fig. 4(A). It started deforming as given in Fig. 4(B), the temperature at this time was defined as the deformation temperature. The temperature, as the sample was heated to a semi-sphere form, shown in Fig. 4(D), was defined as the liquidus temperature. Finally, Fig. 4(E) shows the sample form spreading gradually with the increasing temperature, and this point was named as flow temperature.

\section{Results and Discussions}

In the experimental design, $\mathrm{MgO}, \mathrm{Al}_{2} \mathrm{O}_{3}$ and $\mathrm{C} / \mathrm{S}$ ranged from 0 to $15 \%, 10$ to $20 \%$ and 1.10 to 1.40 , respectively, and the highest operation temperature for slag viscosity measurement was above $1500^{\circ} \mathrm{C}$, and totally forty tests were conducted among these ranges.

\subsection{Softening temperatures of final slag 3.1.1 Observation}

Figure 5 indicates the variation of the softening temperatures measured by observing the deformation of the slag 
(A)Original Form

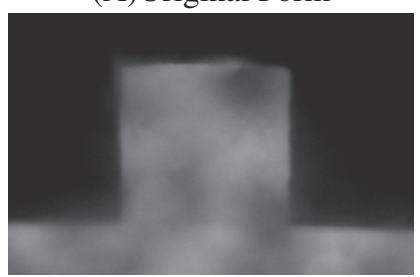

(C)Sphere Temperature (ST)

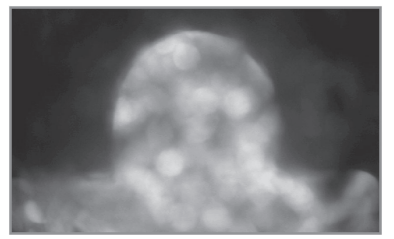

(B)Deformation Temperature (DT)

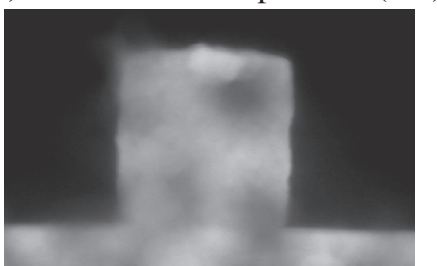

(E)Flow Temperature (FT)

Fig. 4 The softening temperatures based on the deformation of the slag samples.

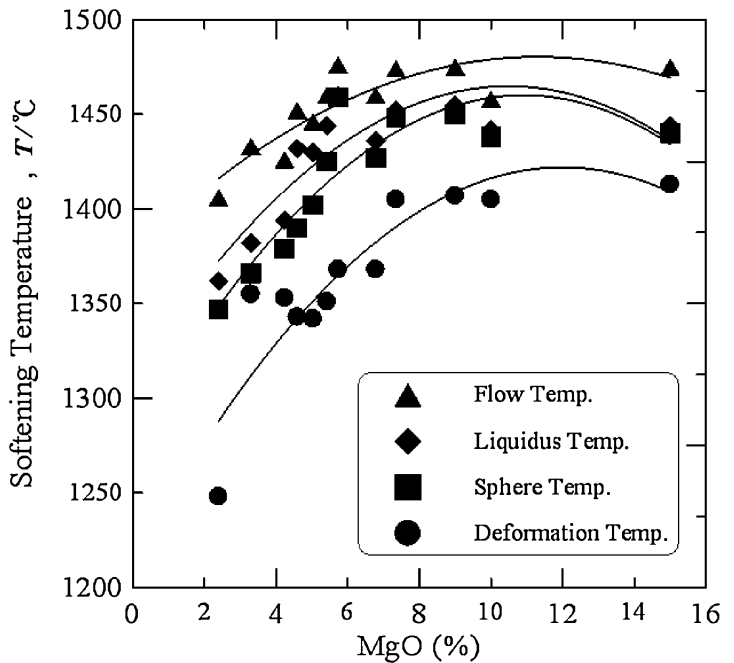

Fig. 5 The variation of the softening temperatures as a function of the $\mathrm{MgO}$ content $(0-15$ mass $\%)$ at $\mathrm{C} / \mathrm{S}=1.2, \quad \mathrm{Al}_{2} \mathrm{O}_{3}=15$ mass $\%$ and $\mathrm{TiO}_{2}=0.5 \operatorname{mass} \%$.

sample as a function of the $\mathrm{MgO}$ content $(0-15$ mass $\%)$ for each slag composition at a basicity of $\mathrm{C} / \mathrm{S}=1.2,15$ mass $\%$ $\mathrm{Al}_{2} \mathrm{O}_{3}$ and 0.5 mass $\% \mathrm{TiO}_{2}$. In this plot, there are four different softening temperatures, comprising the abovedefined flow, liquidus, sphere and deformation temperature from high to low temperature. The curves in Fig. 5 show that the softening temperatures increased gradually then decreased with increasing $\mathrm{MgO}$ content, and that the lower liquidus temperature $\left(<1430^{\circ} \mathrm{C}\right)$ could be obtained in the range of $\mathrm{MgO}$ content from 2.4 to 5.7 mass $\%$. Figure 6 shows the dependence of softening temperature on $\mathrm{C} / \mathrm{S}$ at 5.4 mass $\%$ $\mathrm{MgO}$ and 15 mass $\% \mathrm{Al}_{2} \mathrm{O}_{3}$, where the softening temperatures increased gradually with the increasing $\mathrm{C} / \mathrm{S}$. From the results in Fig. 6, the lower liquidus temperature $\left(<1430^{\circ} \mathrm{C}\right)$ could be obtained in the range of $\mathrm{C} / \mathrm{S}$ from 0.95 to 1.20 . It is shown in Fig. 7 that the dependence of softening temperature on $\mathrm{Al}_{2} \mathrm{O}_{3}$ at a basicity of $\mathrm{C} / \mathrm{S}=1.2,5.4$ mass $\% \mathrm{MgO}$ and 0.5 mass $\%$ $\mathrm{TiO}_{2}$, where the softening temperatures increased gradually with increasing $\mathrm{Al}_{2} \mathrm{O}_{3}$ content. From the results in Fig. 7, the higher liquidus temperature $\left(>1430^{\circ} \mathrm{C}\right)$ could be obtained in the range of $\mathrm{Al}_{2} \mathrm{O}_{3}$ from 17 to $20 \%$.

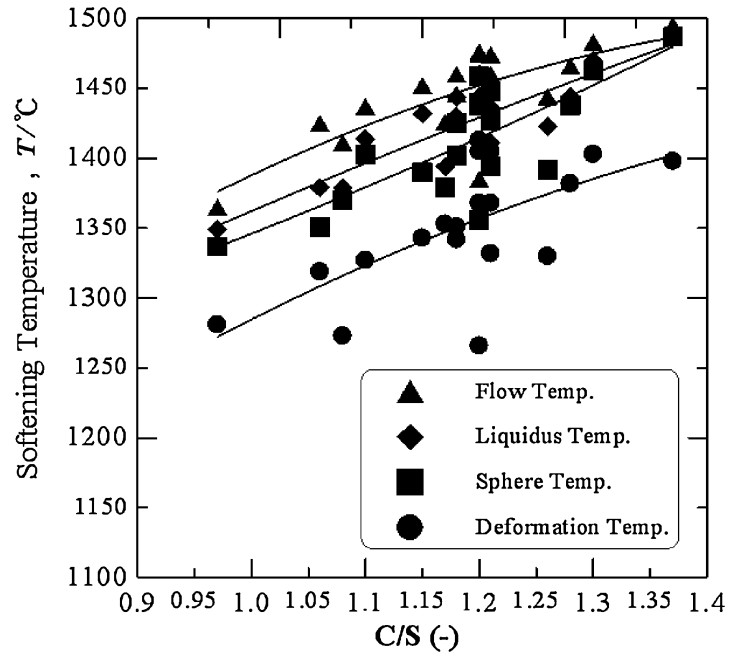

Fig. 6 The dependence of softening temperature on $\mathrm{C} / \mathrm{S}$ at $\mathrm{MgO}=$ 5.4 mass $\%, \mathrm{Al}_{2} \mathrm{O}_{3}=15$ mass $\%$ and $\mathrm{TiO}_{2}=0.5$ mass $\%$.

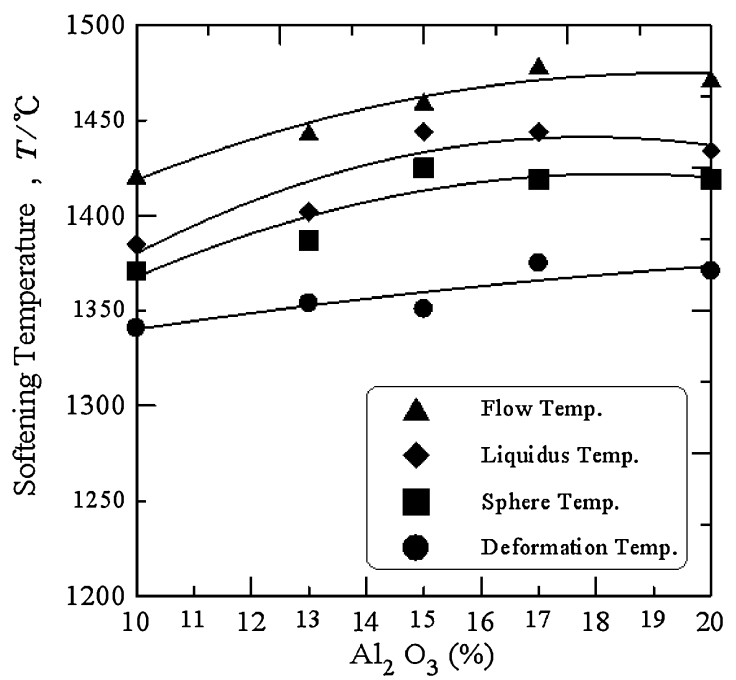

Fig. 7 The variation of the softening temperatures as a function of the $\mathrm{Al}_{2} \mathrm{O}_{3}$ content $(10-20$ mass $\%)$ at $\mathrm{C} / \mathrm{S}=1.2, \mathrm{MgO}=5.4$ mass $\%$ and $\mathrm{TiO}_{2}=0.5 \operatorname{mass} \%$. 


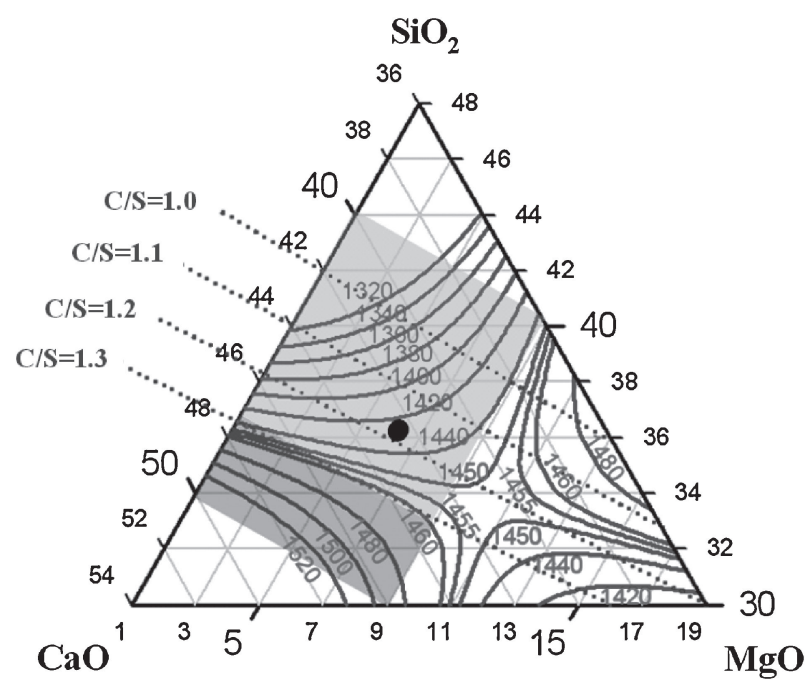

Fig. 8 The liquidus isotherms diagram for $\mathrm{SiO}_{2}-\mathrm{CaO}-\mathrm{Al}_{2} \mathrm{O}_{3}-\mathrm{MgO}-\mathrm{TiO}_{2}$ semi-synthetic slag at $\mathrm{Al}_{2} \mathrm{O}_{3}=15$ mass $\%$ and $\mathrm{TiO}_{2}=0.5$ mass $\%$.

\subsubsection{Multiple regression}

The data for both liquidus temperature $\left(1349-1490^{\circ} \mathrm{C}\right)$ and composition of the slags $\left(31.2-40.3\right.$ mass $\% \mathrm{SiO}_{2}, 38.7-$ 46 mass $\%$ CaO, 10.3-20.4 mass $\% \quad \mathrm{Al}_{2} \mathrm{O}_{3}$ and $0-5$ mass $\%$ $\mathrm{TiO}_{2}$ ) were multiple-regression to get an equation with $R^{2}=0.98$ as eq. (1):

$$
\begin{aligned}
T_{\text {liquidus }}= & \mathrm{aSiO}_{2}{ }^{2}+\mathrm{bCaO}^{2}+\mathrm{cMgO}^{2}+\mathrm{dAl}_{2} \mathrm{O}_{3}{ }^{2} \\
& +\mathrm{eTiO}_{2}{ }^{2}+\mathrm{fSiO}_{2}+\mathrm{gCaO}+\mathrm{hMgO} \\
& +\mathrm{iAl}_{2} \mathrm{O}_{3}+\mathrm{jTiO}_{2}
\end{aligned}
$$

Then, the liquidus isotherms diagram could be obtained by combining the normalized sum of five oxides with the formula with $\mathrm{SiO}_{2}+\mathrm{CaO}+\mathrm{Al}_{2} \mathrm{O}_{3}+\mathrm{MgO}+\mathrm{TiO}_{2}=100 \%$ (as shown in Fig. 8) at 15 mass $\% \mathrm{Al}_{2} \mathrm{O}_{3}$. Each curve in Fig. 8 indicates the distribution of liquidus temperature as a function of slag composition. Based on the distribution of the different liquidus temperatures in this diagram, two distinct regions can be specified. The first region (as blue-colored) is specified for the slag where the liquidus temperature decreases with decreasing $\mathrm{MgO}$ content (when $\mathrm{C} / \mathrm{S}<1.3$, $\mathrm{MgO}<9$ mass\%). The second region (as red-colored) is specified for the slag where the liquidus temperature is not affected by $\mathrm{MgO}$ content (when $\mathrm{C} / \mathrm{S}>1.3$ ). From the result described in the distinct regions of the liquidus isotherms diagram, it is known that the liquidus temperature is favorable for the slag while decreasing the $\mathrm{MgO}$ content under a wide range of $\mathrm{C} / \mathrm{S}$. In terms of the $\mathrm{BF}$ operation range $(1.18<\mathrm{C} / \mathrm{S}<1.20,6.4$ mass $\%<\mathrm{MgO}<6.7$ mass $\%)$ for $\mathrm{CSC}$, the liquidus temperature ranges from 1420 to $1440^{\circ} \mathrm{C}$ and the slag composition is located in the first region, which means that a lower liquidus temperature could be obtained when the $\mathrm{MgO}$ content is reduced.

\subsection{Viscosities of final slag \\ 3.2.1 Observation}

Figure 9 shows the effect of $\mathrm{MgO}$ content on the viscosities of $\mathrm{SiO}_{2}-\mathrm{CaO}-\mathrm{Al}_{2} \mathrm{O}_{3}-\mathrm{MgO}-\mathrm{TiO}_{2}$ semi-synthetic slag as a function of temperature under the conditions of $\mathrm{C} / \mathrm{S}=1.2,15$ mass $\% \mathrm{Al}_{2} \mathrm{O}_{3}$ and 0.5 mass $\% \mathrm{TiO}_{2}$, and these

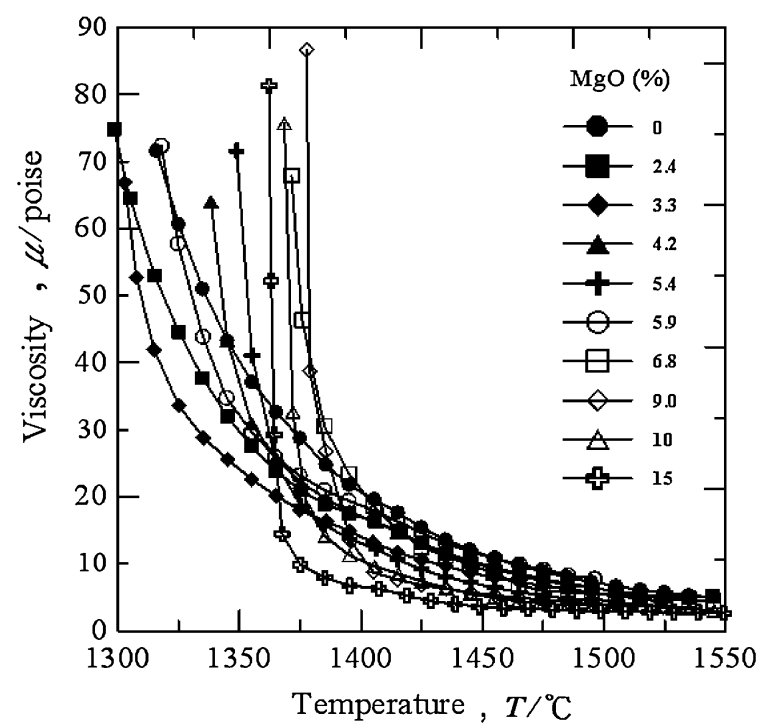

Fig. 9 The effect of $\mathrm{MgO}$ content on the viscosities of $\mathrm{SiO}_{2}-\mathrm{CaO}-\mathrm{Al}_{2} \mathrm{O}_{3}-$ $\mathrm{MgO}-\mathrm{TiO}_{2}$ semi-synthetic slag as a function of temperature at $\mathrm{C} / \mathrm{S}=1.2$, $\mathrm{Al}_{2} \mathrm{O}_{3}=15$ mass $\%$ and $\mathrm{TiO}_{2}=0.5$ mass $\%$.

experimental results indicated that the slag viscosity increases with decreasing slag temperature. However, the curves in Fig. 9 are too complex to easily distinguish the preferable conditions for $\mathrm{BF}$ tapping. For instance, from the curve which stands for the case at 15 mass $\% \mathrm{MgO}$, the viscosity is lower in the high slag temperature range but it becomes higher rapidly in the low temperature range; while for the case of 5.9 mass \% $\mathrm{MgO}$, the viscosity is lower in high temperature range and it increases slowly in the low temperature range. Therefore, in order to determine the better viscosity stability, two criteria were set up. The first criterion for evaluating the stable viscosity was the lower melting temperature $\left(<1400^{\circ} \mathrm{C}\right)$. The melting temperature means the turning point of the curves in Fig. 9, and the results show that most of melting temperatures are lower than $1400^{\circ} \mathrm{C}$ except for the cases of 6.8 and 9.0 mass $\% \mathrm{MgO}$. The second criterion was made to choose the lower viscosity from the lower melting temperatures for the $\mathrm{MgO}$ content in the first criterion. Among the cases of $\mathrm{MgO}$ content lower than the $\mathrm{BF}$ operation range at $\mathrm{CSC}(\mathrm{MgO}=6.4-6.7$ mass\%), it was found that the $\mathrm{MgO}$ content for the most stable viscosity in this work was 5.4 mass\% under the above criteria.

The tendency is observed in the temperature-viscosity curves of slag with different $\mathrm{C} / \mathrm{S}$ values (1.1-1.3) under the conditions of $\mathrm{MgO}=5.4$ mass $\%$ and $\mathrm{Al}_{2} \mathrm{O}_{3}=15$ mass $\%$ (as shown in Fig. 10). Figure 10 shows that a lower melting temperature for slag is observed at $\mathrm{C} / \mathrm{S}=1.2$ by using the above criteria. Therefore, the more stable viscosity in this work is $\mathrm{C} / \mathrm{S}=1.2$. It is also shown that the $\mathrm{BF}$ operation condition for $\mathrm{CSC}(\mathrm{C} / \mathrm{S}=1.18-1.20)$ is located in the suitable range in this study. It is shown in Fig. 11 that the viscosity variation tendency in the temperature-viscosity curves of slag with different $\mathrm{Al}_{2} \mathrm{O}_{3}$ content (10-20 mass $\%$ ) under the conditions of $\mathrm{MgO}=5.4$ mass $\%, 0.5$ mass $\% \mathrm{TiO}_{2}$ and $\mathrm{C} / \mathrm{S}=1.2$. Figure 11 shows that a higher viscosity for slag is observed at the range of $\mathrm{Al}_{2} \mathrm{O}_{3}=17-20$ mass $\%$ by using the above criteria. 


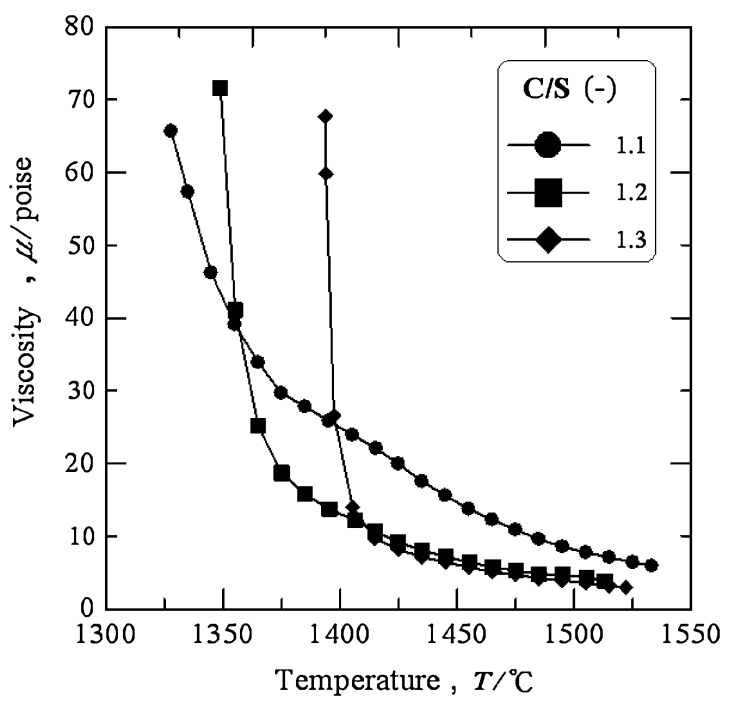

Fig. 10 The effect of $\mathrm{C} / \mathrm{S}$ on the viscosities of $\mathrm{SiO}_{2}-\mathrm{CaO}-\mathrm{Al}_{2} \mathrm{O}_{3}-\mathrm{MgO}-$ $\mathrm{TiO}_{2}$ semi-synthetic slag as a function of temperature at $\mathrm{MgO}=$ 5.4 mass $\%, \mathrm{Al}_{2} \mathrm{O}_{3}=15$ mass $\%$ and $\mathrm{TiO}_{2}=0.5$ mass $\%$.

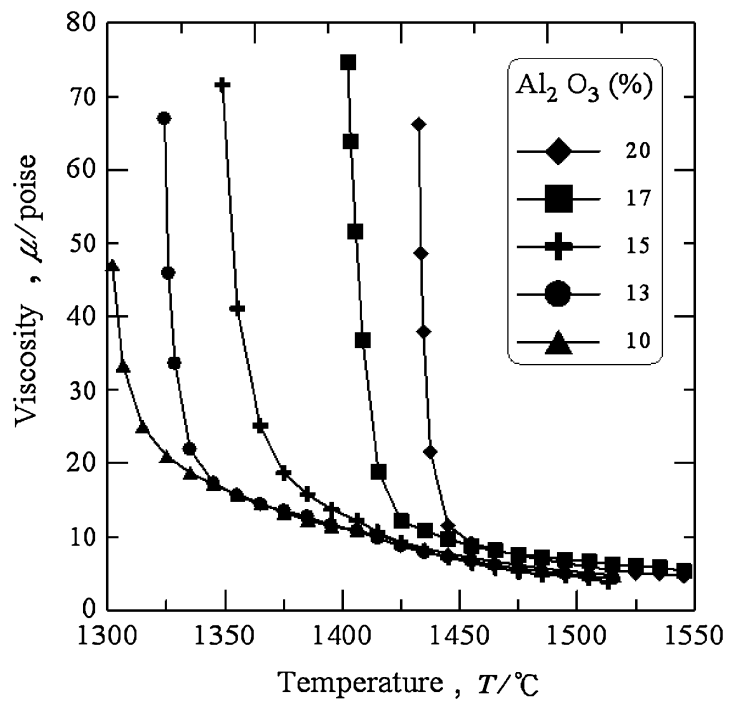

Fig. 11 The effect of $\mathrm{Al}_{2} \mathrm{O}_{3}$ content on the viscosities of $\mathrm{SiO}_{2}-\mathrm{CaO}$ $\mathrm{Al}_{2} \mathrm{O}_{3}-\mathrm{MgO}-\mathrm{TiO}_{2}$ semi-synthetic slag as a function of temperature at $\mathrm{C} / \mathrm{S}=1.2, \mathrm{MgO}=5.4$ mass $\%$ and $\mathrm{TiO}_{2}=0.5$ mass $\%$.

\subsubsection{Multiple regression}

The data for viscosity (2.6-75 poise), composition of the slags (the same ranges as liquidus temperature cases), and slag temperature were multiple-regression to get an equation with $R^{2}=0.97$ as eq. (2):

$$
\begin{aligned}
\mu= & \mathrm{a}^{\prime} \mathrm{SiO}_{2}{ }^{2}+\mathrm{b}^{\prime} \mathrm{CaO}^{2}+\mathrm{c}^{\prime} \mathrm{MgO}^{2}+\mathrm{d}^{\prime} \mathrm{Al}_{2} \mathrm{O}_{3}{ }^{2} \\
& +\mathrm{e}^{\prime} \mathrm{TiO}_{2}{ }^{2}+\mathrm{f}^{\prime} \mathrm{SiO}_{2}+\mathrm{g}^{\prime} \mathrm{CaO}+\mathrm{h}^{\prime} \mathrm{MgO} \\
& +\mathrm{i}^{\prime} \mathrm{Al}_{2} \mathrm{O}_{3}+\mathrm{j}^{\prime} \mathrm{TiO}_{2}+\mathrm{k}^{\prime} \mathrm{T}^{2}+\mathrm{l}^{\prime} \mathrm{T}
\end{aligned}
$$

The iso-viscosity distribution diagram can be obtained in the diagram $\left(\mathrm{Al}_{2} \mathrm{O}_{3}=15\right.$ mass $\%$, slag temperature $=$ $1500^{\circ} \mathrm{C}$ ) by using the same calculation method as above the isotherms diagram, as shown in Fig. 12. Each curve in Fig. 12 describes the distribution of viscosity related to the slag composition, with that also two distinct regions can be specified. The first region (as blue-colored) is specified for

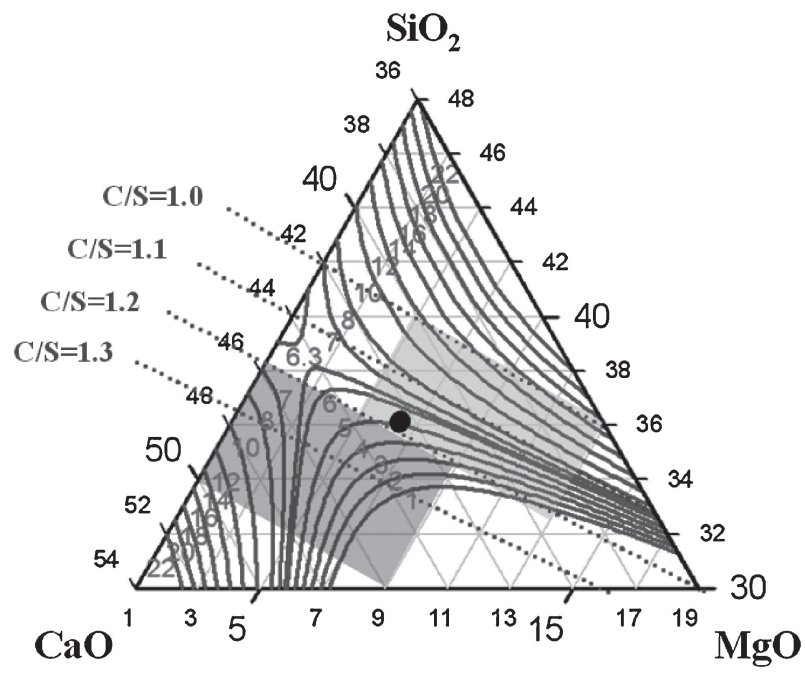

Fig. 12 The iso-viscosity diagram for $\mathrm{SiO}_{2}-\mathrm{CaO}-\mathrm{Al}_{2} \mathrm{O}_{3}-\mathrm{MgO}-\mathrm{TiO}_{2}$ semisynthetic slag at $1500^{\circ} \mathrm{C}, \mathrm{Al}_{2} \mathrm{O}_{3}=15$ mass $\%$ and $\mathrm{TiO}_{2}=0.5$ mass $\%$.

the slag where viscosity is not affected by $\mathrm{MgO}$ contents (when $\mathrm{C} / \mathrm{S}=1.0-1.2, \mathrm{MgO}=5-13$ mass $\%$ ). The second region (as red-colored) is specified for the slag where the viscosity increases with decreasing $\mathrm{MgO}$ content (when $\mathrm{C} / \mathrm{S}>1.2, \mathrm{MgO}<9 \%$ ). Therefore, there is no influence on the final viscosity by reducing $\mathrm{MgO}$ when $\mathrm{C} / \mathrm{S}=1.0-1.2$. In terms of the $\mathrm{BF}$ operation range for $\mathrm{CSC}$, the slag viscosity ranges from 5 to 6 poise and the slag composition approaches to the first region. However, the dominant factor for avoiding high viscosity is $\mathrm{C} / \mathrm{S}$, and good slag viscosity can be still obtained as long as $\mathrm{C} / \mathrm{S}$ is precisely controlled to about 1.20 .

The iso-viscosity distribution diagrams (for 15 mass $\%$ $\mathrm{Al}_{2} \mathrm{O}_{3}$ at 1450 and $1400^{\circ} \mathrm{C}$, respectively) could be also developed in this study, as shown in Fig. 13. It was found that the distribution tendency of slag viscosity was similar to the distribution tendency for $1500^{\circ} \mathrm{C}$, the only difference being the lower slag temperature, the higher slag viscosity at the same composition. The slag viscosities are respectively $8-9$ poise at $1450^{\circ} \mathrm{C}$ and $16-17$ poise at $1400^{\circ} \mathrm{C}$ for the $\mathrm{BF}$ operation range in CSC. In addition, Fig. 14 shows the diagram for slag isotherms as a function of compositions at a fixed viscosity ( $=8$ poise) by using the same calculation method as the iso-viscosity diagram, and the directions of the two arrowheads in this plot indicates that the slag temperature goes from low to high temperature. It is observed that slag temperature should be higher than $1450^{\circ} \mathrm{C}$ to keep the slag viscosity in 8 poise; however, it needs a much higher slag temperature while maintaining the better slag fluidity.

\subsection{Comparison of liquidus isotherms with slag iso- therms}

Comparing the results of Fig. 8 with Fig. 14, it is shown that the liquidus temperature will decrease as reducing the $\mathrm{MgO}$ content from the CSC's BF operation range (6.46.7 mass $\%$ ) to 5 mass $\%$, and there is only minor effect on the slag temperature $\left(<5^{\circ} \mathrm{C}\right)$. It follows from above-mentioned that the $\mathrm{MgO}$ content could be lowered from current 6.5 

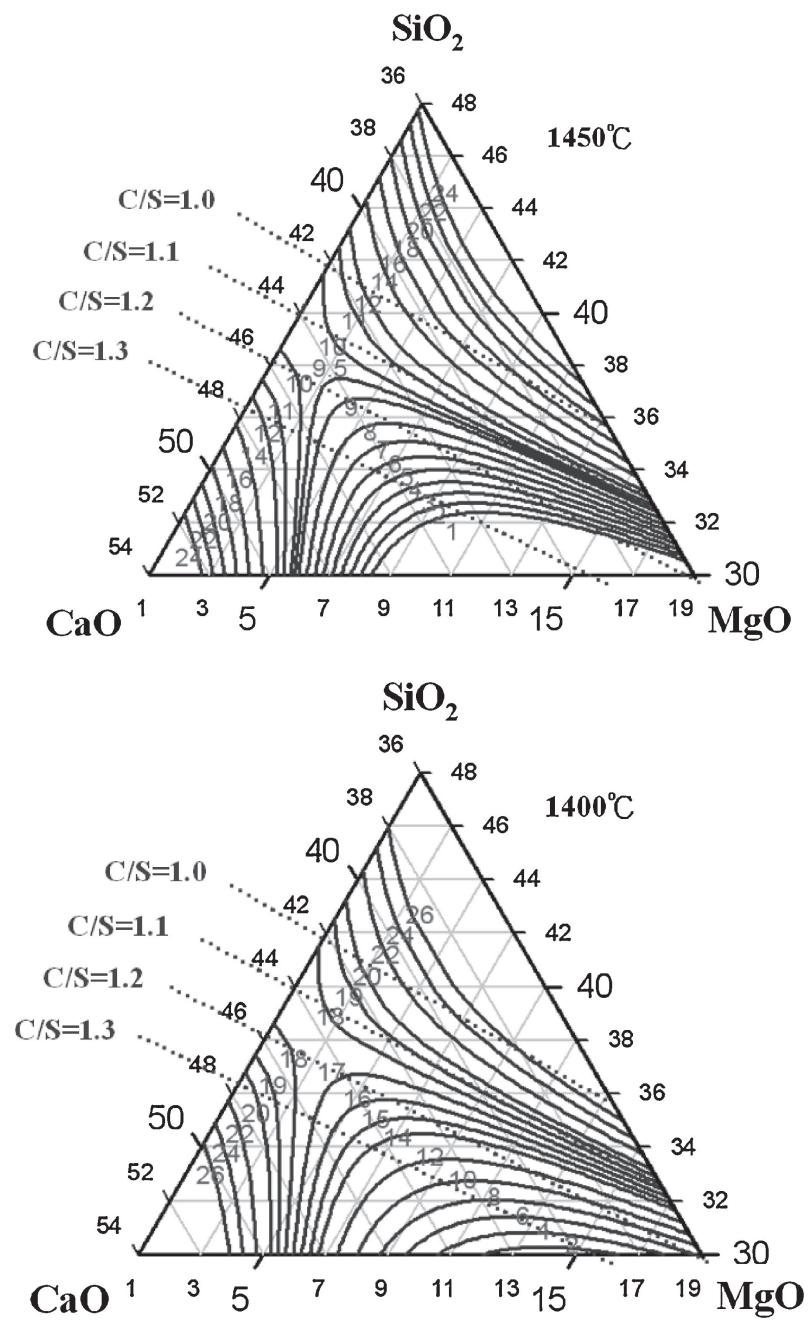

Fig. 13 The iso-viscosity diagram for $\mathrm{SiO}_{2}-\mathrm{CaO}-\mathrm{Al}_{2} \mathrm{O}_{3}-\mathrm{MgO}-\mathrm{TiO}_{2}$ semisynthetic slag at 1450 and $1400^{\circ} \mathrm{C}\left(\mathrm{Al}_{2} \mathrm{O}_{3}=15\right.$ mass $\%$ and $\mathrm{TiO}_{2}=$ $0.5 \operatorname{mass} \%$ ).

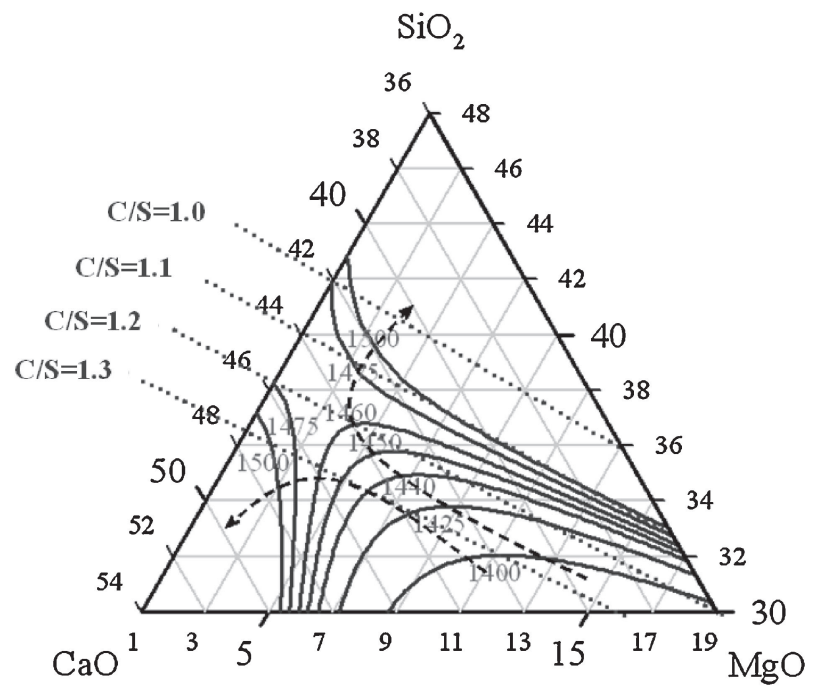

Fig. 14 The slag isotherms diagram for $\mathrm{SiO}_{2}-\mathrm{CaO}-\mathrm{Al}_{2} \mathrm{O}_{3}-\mathrm{MgO}-\mathrm{TiO}_{2}$ semi-synthetic slag at fixed viscosity ( $=8$ poise), $\mathrm{Al}_{2} \mathrm{O}_{3}=15$ mass $\%$ and $\mathrm{TiO}_{2}=0.5$ mass $\%$.

to 5.4 mass $\%$ in the conditions of $\mathrm{Al}_{2} \mathrm{O}_{3}=15$ mass $\%$, $\mathrm{TiO}_{2}=0.5$ mass $\%$ and $\mathrm{C} / \mathrm{S}=1.2$ under the stable blast furnace operation with the high thermal level.

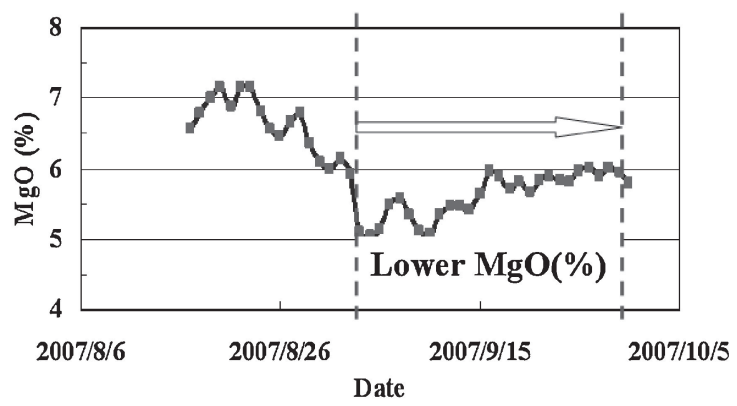

\begin{tabular}{|l|c|c|}
\hline & MgO (\%) & Slag Volume (kg/tHM) \\
\hline 2006 (avg.) & 6.5 & 266 \\
\hline 2007.09 & 5.5 & 259 \\
\hline
\end{tabular}

Fig. 15 The practical results of lower $\mathrm{MgO}$ content in CSC's BF.

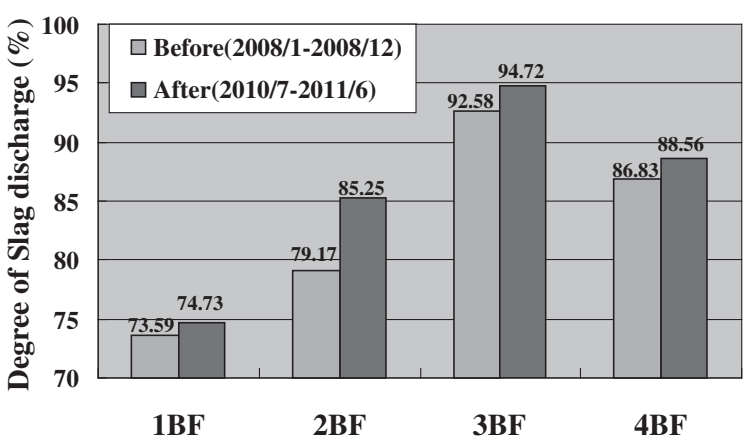

Fig. 16 Degree of BF slag discharge for each hot metal tapping in CSC's BFs.

\subsection{Applications \\ 3.4.1 Lower slag volume rate inside BF}

S. H. Yi and J. R. Kim showed that the permeability was not changed at the bosh zone when the $\mathrm{MgO}$ content was decreased from 6.2 to $4.1 \%$, and good slag fluidity was obtained under the conditions of slag basicity $(\mathrm{C} / \mathrm{S})=1.18$ and $\mathrm{MgO}=5 \%{ }^{2,3)} \mathrm{K}$. Higuchi also indicated that when the $\mathrm{MgO}$ content decreased to $5.4 \%$, the blast furnace operation cost and slag volume were reduced. ${ }^{4)}$ In this study, it was suggested the suitable lower $\mathrm{MgO}$ content was at $5.4 \%$, and it had been adopted in CSC's BFs. One example was shown in Fig. 15, and the practical results indicated slag volume was actually reduced by using $5.5 \% \mathrm{MgO}$ of final slag.

\subsubsection{Real-time system for BF slag fluidity}

The interruption of slag flow often occurs with the bad permeability for hot metal flow inside BF hearth, and seriously affect the stability of furnace practice. The bad permeability for liquid flow is usually caused by the bad slag fluidity, which can be expressed by using the index such as slag liquidus temperature and viscosity. The developed formula of slag liquidus temperature and viscosity had been installed in the process computer of all CSC's BFs to present slag fluidity in real time. This system can immediately provide BF staffs some information to control the variation of slag fluidity by making the effective operating adjustment. After installing this system, the degree of BF slag discharge for each hot metal tapping was increased in CSC's BFs (as Fig. 16), and a more stable BF operation was achieved. 


\section{Conclusion}

From above investigation, the following conclusions are drawn:

(1) Experimental results indicate that the lower liquidus temperature and the better viscosity stability of slags lay in the conditions of $\mathrm{MgO}=5.4 \%, \mathrm{Al}_{2} \mathrm{O}_{3}=15 \%$, $\mathrm{TiO}_{2}=0.55 \%$ and $\mathrm{C} / \mathrm{S}=1.2$ for the variation of $\mathrm{MgO}$ contents $(0-15 \%)$. And slag fluidity became worse with the increase of $\mathrm{Al}_{2} \mathrm{O}_{3}$ content for the range of composition studied.

(2) The observations in the liquidus isotherms and isoviscosity diagrams of blast furnace final slag show that liquidus temperature decreases with decreasing $\mathrm{MgO}$ content and the viscosity of slag could be regarded as being independent of $\mathrm{MgO}$ content in the range of
$\mathrm{MgO}=5-9 \operatorname{mass} \%, \quad \mathrm{Al}_{2} \mathrm{O}_{3}=15$ mass $\%, \mathrm{C} / \mathrm{S}=1.0-$ 1.2 .

(3) The lower $\mathrm{MgO}$ content (5.4\%) had been implemented to reduce the slag volume, and the real-time system for BF slag fluidity had been installed in all CSC's BFs as useful tool for daily operation.

\section{REFERENCES}

1) J. S. Shiau and S. H. Liu: Min. Metall. 52 (2007) 44-50.

2) S. H. Yi and W. W. Huh: Proc. Int. BF Lower Zone Sym., (AusIMM, 2002) pp. 1-6.

3) J. R. Kim, Y. S. Lee, D. J. Min, S. M. Jung and S. H. Yi: ISIJ Int. 44 (2004) 1291-1297.

4) K. Higuchi, Y. Takamoto, T. Orimoto, T. Sato, F. Koizumi, K. Shinagawa and H. Furuta: Nippon Steel Tech. Report 94 (2006) 3641. 